\title{
Decomposition of corn and soybean residues under field conditions and their role as inoculum source
}

\author{
Erlei Melo Reis ${ }^{1}$, Doglas Baruffi, Luciano Remor and Mateus Zanatta
}

Universidade de Passo Fundo, Faculdade de Agronomia e Medicina Veterinária, Passo Fundo - RS; ${ }^{1}$ Bolsista do CNPq

Autor para correspondência: Erlei Melo Reis (erleireis@tpo.com.br)

Data de chegada: 26/06/2009. Aceito para publicação em: 25/01/2011.

\section{ABSTRACT}

Reis, E. M.; Baruffi, D.; Remor, L; Zanatta, M. Decomposition of corn and soybean residues under field conditions and their role as inoculum source. Summa Phytopathologica, v.37, n.1, p.65-67, 2011.

Necrotrophic parasites of above-ground plant parts survive saprophytically, between growing seasons in host crop residues. In an experiment conducted under field conditions, the time required in months for corn and soybean residues to be completely decomposed was quantified. Residues were laid on the soil surface to simulate notill farming. Crop debris of the two plant species collected on the harvesting day cut into pieces of $5.0 \mathrm{~cm}-10 n g$ and a $200 \mathrm{~g}$ mass was added to nylon mesh bags. At monthly intervals, bags were taken to the laboratory for weighing. Corn residues were decomposed within 37.0 months and those of soybean, within 34.5 months. Hw main necrotrophic fungi diagnosed in the corn residues were Colletotrichum gramicola, Diplodia spp. and Gibberella zeae, and those in soybeans residues were Cercospora kikuchii, Colletotrichum spp, Glomerella sp. and Phomopsis spp. Thus, those periods shoulb be observed in crop rotation aimed at to eliminating contaminated residues and, consequently, the inoculum from the cultivated area.

Palavras-chave adicionais: necrotrophic parasites, crop residues, time of decomposition.

\section{RESUMO}

Reis, E. M.; Baruffi, D.; Remor, L; Zanatta, M. Decomposição dos restos culturais do milho e da soja sob condições de campo e sua função como fonte de inóculo primário. Summa Phytopathologica, v.37, n.1, p.65-67, 2011.

Parasitas necrotróficos de órgãos aéreos sobrevivem saprofiticamente, na esntre-safra, nos restos culturais dos hospedeiros. Em experimento conduzido no campo quantificou-se o tempo, em meses, para a decomposição dos restos culturais do milho e da soja, posicionados na superfície do solo simulando o plantio direto. Os restos culturais das duas espécies foram coletados no dia da colheita mecânica, cortados em peças de $5,0 \mathrm{~cm}$ de comprimento e uma massa de $200 \mathrm{~g}$ acondicionada em recipientes de malha de náilon. Mensalmente foram removidos do campo e levados ao laboratório aonde se procedeu a pesagem. Demonstrou-se que os restos culturais do milho foram mineralizados num tempo de 37 meses e os da soja em 34,5 meses. Os principais fungos necrotróficos parasitas diagnosticados em resíduos de milho foram Colletotrichum gramicola, Diplodia spp. e Gibberella zeae, e nos restos culturais da soja Cercospora kikuchii, Colletotrichum spp, Glomerella sp e Phomopsis spp. Pode-se inferir que estes são os tempos a serem observados na rotação de culturas visando à redução dos restos culturais e conseqüentemente do inóculo na área cultivada.

Keywords: parasitas necrotróficos, restos de cultura, tempo de decomposição.

The knowledge of the biology of plant pathogens may help to explain, where and for how long they survive in the absence of the live host plant. Such information may be important in the development of disease control strategies (6)

During the survival phase, the necrotrophic parasites of aboveground plant parts are separated from their host in the saprophytic phase, they generally are submitted to intense microbial competition, in which, generally, they are in disadvantage (10). During the survival they are under the risk of not encountering the host, what may determine their death by starvation (4).

The most evoluted way that ensures with larger frequency the continuity of the life cycle of a parasitic specie is not to separate from the live host, or crop residues, or seeds. In those cases where pathogens had been separate from host for a span of time longer than six or seven months (life cycle of annual plant species), they should count on resting structures, which give them the chance to wait for longer period of time until the plant be cultivated again in the same area under monoculture (11)

Plant pathogens of above ground plant parts may survive associated to the seeds and to crop debris. Those that do not present resting structures, and thus are active in the saprophytic phase, remain viable in the soil during the period they explore host residues nutrients (11).

The survival mechanisms of plant pathogens has been reviewed by Reis \& Casa (11). Many fungi survive on debris from harvested soybean. For example, Diaporthe phaseolorum (Cooke \& Ellis) Sacc. var. sojae (S. G. Lehman) Wehmeyer and Phomopsis spp. survive and sporulate on this tissue, providing inoculum for the following growing season. Other fungi reported to overwinter on soybean stem and pod 
debris include Alternaria, Colletotrichum, Diaporthe, Phoma, and Septoria. Furthermore, species of Colletotrichum and Diaporthe (anamorph Phomopsis), including C. destructivum O'Gara (teleomorph Glomerella glycines Lehm. \& Wolf), C. truncatum (Schwein.) Andrus \& Moore, D. Phaseolorum var. sojae, P. longicolla Hobbs, and D. phaseolorum var. caulivora Athow \& Caldwell, have been found to overwinter as saprophytes on dormant mycelium in soybean stems, pods, and seeds and on other host debris $(1,2,8)$.

Surviving in corn residues have been reported for Bipolaris maydis (Nisik.) Shoem., Cercospora zea-maydis Tehon \& Daniels, Colletotrichum graminicola (Ces.) Wis., Diplodia maydis Berk, D. macrospora Earle, Exserohilum turcicum (Pass.) Leonard \& Suggs., and Kabatiella zeae Narita \& Hiratsuka (17). Those pathogens for both corn and soybean, have no other mechanisms for survival than seed infection and crop residue.

Researchers have reported that soybean disease levels of anthracnose, southern stem canker, and white mold were greater in no-tillage systems than in systems using conventional practices (5, $14,16)$.

The objective of this work was to quantify the required time for corn and soybean crop residues decomposition, under natural conditions, and use this information as a criterion to decide when the respective crops should return to be cultivated in the same area.

Soon after the mechanical harvest of corn and soybean, in May 2004, crop residues left on soil surface were collected in an experimental area of the University of Passo Fundo, RS state, Brazil. Plant residues were cut into pieces of $5.0 \mathrm{~cm}$ long and corn stalks splitted into halves. Two-hundred grams of residues of crops were separately packed in nylon mesh bags (anti-insect screen) $0.30 \mathrm{x} 0.3 \mathrm{~m}$ and taken to the field where they were laid on the soil surface simulating no-till farming. During the assessing period, the soil was cultivated with soybeans and corn in the summer and with oat, wheat and rape in the winter. At monthly intervals, two bags for each crop specie were removed, brought to the laboratory, washed with a soft jet of tap water, let to dry in the air until reach constant weight and weighed the residues outside the containers. Pieces of the residues for both crops in the first and in the $15^{\text {th }}$ month were removed from the bags and stored in moist chamber in acrylic boxes to induce development of reproduction structures and sporulation to be easy the process of pathogens identification.

Results are expressed in percentage of the weight in grams considering the initial $200 \mathrm{~g}$ equal to $100 \%$. Data were submitted to analysis of variance and regression analysis.

The following fungi were identified associated to corn stalks: Colletotrichum gramicola, Diplodia spp., and Gibberella zeae (12) and in soybeans stems Cercospora kikuchii, Colletrotrichum spp, Glomerella sp, and Phomopsis spp.

Soybean crop residues mineralized in a time period of 34.5 months estimated with the linear function $\mathrm{D}=80.379-2.3297 \mathrm{t}$ with coefficient of determination $\mathrm{R} 2=0.95(p=0.000001)$, where $\mathrm{D}=$ decomposition (\%) and $\mathrm{t}=$ time in months (Fig. 2). Costamilan et al. (6) determined a time of 27.0 months for soybean straw decomposition. The difference between 27.0 and 34.5 , may be attributed to the climatic contrasts occurred in the two experiments carried out at different times and sites.

The potential control of plant pathogens by crop rotation has been discussed by Reis et al. (3 e 11).

In this was used Casa et al (3) methodology to quantify the time required in months for corn and soybeans crop debris mineralization. However, the nylon mesh bags may had some effect in delaying the

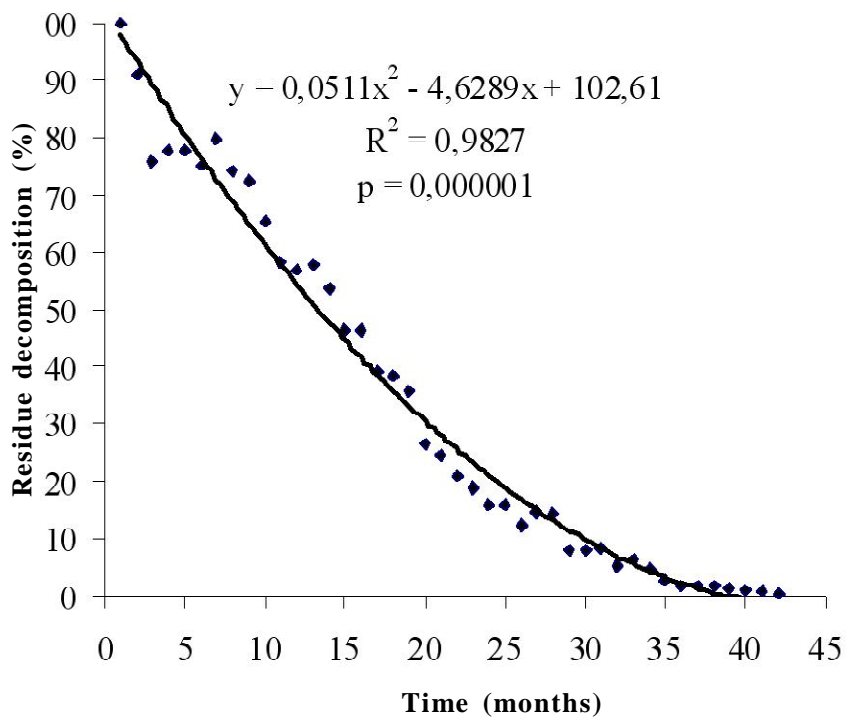

Figure 1. Decomposition of corn residues under field conditions, as a function of time. Time started in May, 2004. Dots represent observed values and the line the regression. Passo Fundo 2008.

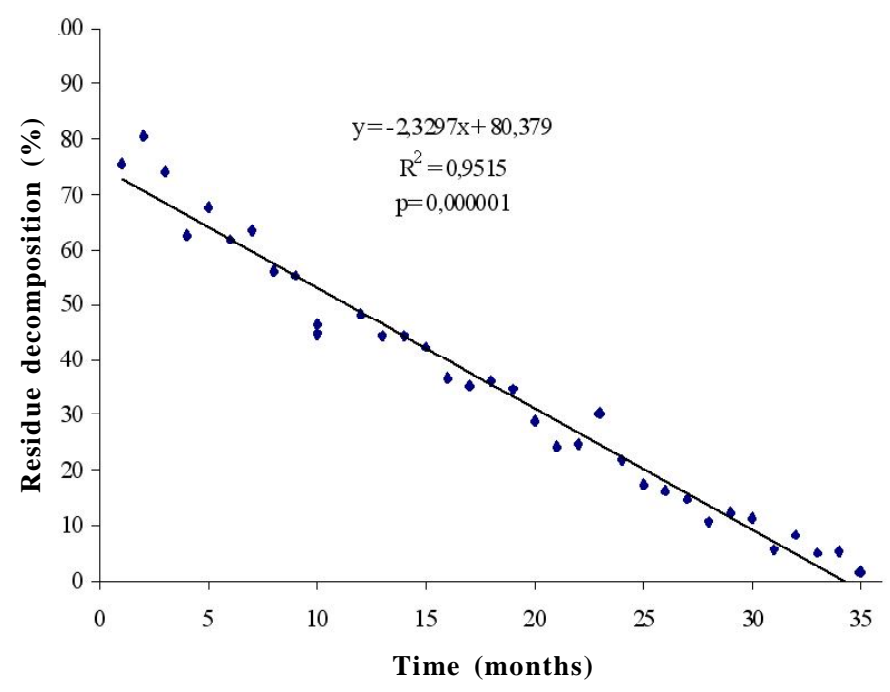

Figure 2. Decomposition of soybean crop residues under field condition, as a function of time. Time started in May 2004. Dots are observed values and the line the regression. Passo Fundo 2008.

decomposition process and thus not reflecting perfectly what occurs in the field. Due to the crop residues exposition to weather, and microbial decomposition, there was a biomass reduction along the time (Figs. 1 e 2).

Corn crop residues were mineralized in a period of 37.0 months using for calculation the quadratic function $\mathrm{D}=102.61-4.62589 \mathrm{t}-$ $0.00511 \mathrm{t} 2$, with coefficient of determination $\mathrm{R} 2=0.98(p=0.000001)$ (Fig. 1).

Casa et al (3), in a similar work, estimated in 32.0 to 38.0 months the required time for corn residue decomposition, a similar value obtained in the present work.

The speed of residue microbial decomposition is a function of temperature, water potential of the substratum, $\mathrm{pH}, \mathrm{C} / \mathrm{N}$ ratio and, the diversity of the present microbiota at the experimental site (14). 
The following fungi were identified associated to corn stalks: Colletotrichum graminicola, Diplodia spp., and G. zeae (12) and in soybeans stems C. kikuchii, Colletotrichum spp, Glomerella sp, and Phomopsis spp.

During crop rotation, period of time when the host is not cultivated, the plant residues are gradually broken down and, as a consequence, the inoculum of necrotrophic pathogens of above ground plant parts that do not have resting structures, are reduced or eliminated.

This paper may contribute to answer the questions: when a crop may return to be cultivated in the same farm area? How to determine the rotation period for one given plant specie?

Necrotrophic parasitic fungi and bacteria from above-ground plant parts of corn and soybean that do not present competitive saprophytic ability, survive saprophitically and actively in the crop residues are controlled by rotation, excepting Sclerotinia sclerotiorum (Lib.) de Bary, which produces resting structures such as sclerotia $(8,9,10)$.

Nevertheless, pathogens with saprophytic competitive ability are not controlled by rotation but mainly through the development of soil supressiveness. Hence, Rhizoctonia solani Kühn, Macrophomina phaseoli (Tassi) Goid., Fusarium graminearum Shwab., Fusarium verticillioides Sheld., causing root rots in their hosts are not controlled by crop rotation with non host crops (4).

It has been demonstrated the importance of crop residues for saprophitical survival of some fungus plant pathogens in such a way that the presence of crop residues means the presence of the necrotrophic parasite in the farm land (13) and the importance of crop rotation to control pathogens in the saprophytic phase.

This work reinforces the concepts of monoculture and of crop rotation under the plant pathology point of view as stated by Reis et al. (12).

\section{REFERENCES}

1. Baird, R. E.; Mullinix, B. G.; Peery, A. B.; Lang, M. L. Diversity and longevity of the soybean debris mycobiota in a no-tillage system. Plant Disease, Saint Paul. v. 81, p.530-534, 1997.

2. Broders, K. D., Lipps, P. E., Paul, P. A., and Dorrance, A. E. 2007. Evaluation of Fusarium graminearum associated with corn and soybean seed and seedling disease in Ohio. Plant Disease, Saint Paul. V.91, p.1155-1160, 2007.
3. Casa, R. T.; Reis, E. M.; Zambolim, L. Decomposição dos restos culturais do milho e sobrevivência saprofítica de Stenocarpella macrospora e $S$. maydis. Fitopatologia Brasileira, Fortaleza v. 28, p. 355-361, 2003.

4. Cook, R. J.; Baker, K.F. The nature and practice of biological control of plant pathogens. The American Phytopathological Society. St. Paul, 1983. 539p.

5. Cook, R. J.; Boosalis, M. G.; Doupnik, B. Influence of crop residues on plant diseases. Pages 147-163 in: Crop Residue Management Systems. Amer. Soc. Agron. Spec. Publ. 31. Madison, WI. 1978

6. Coley-Smith, J. R. Survival of plant-pathogenic fungi in soil in the absence of host plants. In: SCHIPPERS, B.S.; CAMS, W. (Eds.). Soil borne plant pathogens. London: Academic Press. 1979. Cap.4, p.39-57.

7. Costamilan, L. M.; Lhamby, J. C. B.; Bonato, E. R. Sobrevivência de fungos necrotróficos em restos de cultura de soja, em sistema de plantio direto. Fitopatologia Brasileira, Fortaleza, v. 24, p. 175-177, 1999.

8. Hartman, G. L.; Sinclair, J. B.; Rupe, J. C. Compendium of soybeans disease. Saint Paul, APS Press. 1999. 100 p.

9. Menzies, J. D. Survival of microbial plant pathogens in soil Botanical Review New York, v.29, p.79-112, 1963.

10. Menzies, J. D. Occurrence and transfer of biological factor in soil that suppresses potato scab. Phytopathology, Saint Paul, v.49, p. 648-652, 1959

11. Reis, E. M. \& Casa,; R. T. Sobrevivência de fitopatógenos. In: Vale, F. X. R.; Cintra de Jesus, V.; Zambolim, L. (Org.). Epidemiologia aplicada ao manejo de doenças de plantas. Belo Horizonte: Editora Perfil, 2004. v.1. p. 335-364.

12. Reis, E.; Casa, R. T.; Bresolin, A. C. R. Manual de diagnose e controle de doenças do milho. 2. Ed. Lages: Graphel, 2004. $144 \mathrm{p}$.

13. Reis E.M.; Silva, C.A.; Casa, R.T.; Medeiros, C.A. Decomposição dos restos culturais de trigo e sobrevivência saprofítica de Bipolaris sorokiniana. Fitopatologia Brasileira, Fortaleza v.23, p.62-64, 1998.

14. Rothrock, C. S.; Hobbs, T. W.; Phillips, D. V. Effects of tillage and cropping system on incidence and severity of southern stem canker of soybean. Phytopathology Saint Paul, v.75, p. 11561159,1985 .

15. Santos , H. P. dos; Reis, E.M. Rotação de culturas em plantio direto. Efeitos de sistemas rotação de culturas sobre o controle de doenças. Passo Fundo, RS, Embrapa Trigo, 2001. 212 p.

16. Summer, D. R.; Doupnik, B., Jr.; Boosalis, M. G. Effects of reduced tillage and multiple cropping on plant diseases. Annual Review Phytopathology, Palo Alto, v. 19, p.167-187, 1981.

17. White, D. G. Compendium of corn diseases. 3. ed. Saint Paul, APS Press, $1999.78 \mathrm{p}$. 